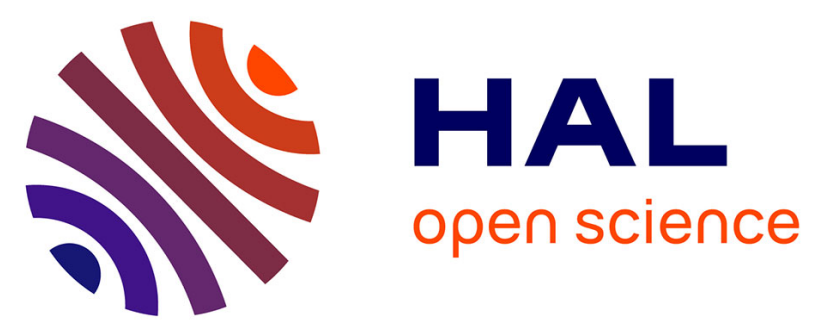

\title{
Preface - Special issue applied geochemistry: Innovative methods for characterizing evolution and budgets in water/rock systems: A tribute to Tom Bullen and Stepan Shvartsev
}

Romain Millot, Orfan Shouakar-Stash, Pierpaolo Zuddas, Ludmila P Alexeeva

\section{To cite this version:}

Romain Millot, Orfan Shouakar-Stash, Pierpaolo Zuddas, Ludmila P Alexeeva. Preface - Special issue applied geochemistry: Innovative methods for characterizing evolution and budgets in water/rock systems: A tribute to Tom Bullen and Stepan Shvartsev. Applied Geochemistry, 2021, 127, 10.1016/j.apgeochem.2021.104892 . hal-03285540

\section{HAL Id: hal-03285540 \\ https: / hal-brgm.archives-ouvertes.fr/hal-03285540}

Submitted on 19 Jul 2021

HAL is a multi-disciplinary open access archive for the deposit and dissemination of scientific research documents, whether they are published or not. The documents may come from teaching and research institutions in France or abroad, or from public or private research centers.
L'archive ouverte pluridisciplinaire HAL, est destinée au dépôt et à la diffusion de documents scientifiques de niveau recherche, publiés ou non, émanant des établissements d'enseignement et de recherche français ou étrangers, des laboratoires publics ou privés. 


\section{Journal Pre-proof}

Preface - Special Issue Applied Geochemistry Innovative methods for characterizing evolution and budgets in water/rock systems: A tribute to Tom Bullen and Stepan

Shvartsev

Romain Millot, Orfan Shouakar-Stash, Pierpaolo Zuddas, Ludmila P. Alexeeva

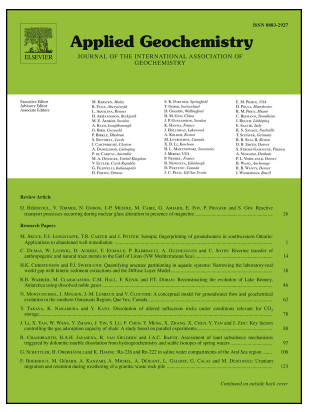

PII:

S0883-2927(21)00024-X

DOI:

https://doi.org/10.1016/j.apgeochem.2021.104892

Reference: $\quad$ AG 104892

To appear in: Applied Geochemistry

Received Date: 15 January 2021

Accepted Date: 15 January 2021

Please cite this article as: Millot, R., Shouakar-Stash, O., Zuddas, P., Alexeeva, L.P., Preface - Special Issue Applied Geochemistry Innovative methods for characterizing evolution and budgets in water/rock systems: A tribute to Tom Bullen and Stepan Shvartsev Applied Geochemistry, https://doi.org/10.1016/ j.apgeochem.2021.104892.

This is a PDF file of an article that has undergone enhancements after acceptance, such as the addition of a cover page and metadata, and formatting for readability, but it is not yet the definitive version of record. This version will undergo additional copyediting, typesetting and review before it is published in its final form, but we are providing this version to give early visibility of the article. Please note that, during the production process, errors may be discovered which could affect the content, and all legal disclaimers that apply to the journal pertain.

(c) 2021 Elsevier Ltd. All rights reserved. 


\title{
Preface - Special Issue Applied Geochemistry
}

\section{Innovative methods for characterizing evolution and budgets in water/rock systems: A tribute to Tom Bullen and Stepan Shvartsev}

\author{
Romain Millot, Orfan Shouakar-Stash, Pierpaolo Zuddas, Ludmila P. Alexeeva
}

\section{1- Background}

Recent theoretical and analytical developments of isotope systematics have resulted in an unprecedented increase in the volume of research on past and present terrestrial and aquatic systems. Similarly, advances in geochemical understanding of trace element mobility in water-rock interaction systems has also significantly increased. The aim of this Special Issue dedicated to the late Tom Bullen and Stepan Shvartsev was to document recent advances in methods, tracers and applications water-rock interaction and isotopes with the objective to provide 1) stronger constraints on the origin(s) of elements, 2) a better characterization of the processes controlling their budgets, and 3) historical records of variations of their cycles in water-rock interaction systems at local and global scales. The aim of this Special Issue was also to integrate complementary approaches to provide new insights into trace element behaviour during water-rock interactions.

This Special Issue contains 37 papers written by authors from 10 countries: Canada, China, Cyprus, Czech Republic, Denmark, France, Italy, Russian Federation, Sweden and United States of America.

This collection of papers is mainly focused on five topics: 1) groundwater hydrogeochemistry, 2) soil and critical zone characterization, 3) environmental fingerprinting and monitoring, 4) climate change and geochemical records and 5) bio-geochemistry of water/rock interactions.

More specifically, this Special Issue gather innovative use of spectroscopic techniques, multi-isotopic systematics, and thermodynamic or kinetic approaches providing stronger constraints on the origin (both natural and anthropogenic) and better characterization of the processes controlling the geochemical behaviour of trace elements in the environment (e.g., soil, sediment, aquifer, etc.). This Special Issue brings together friends of Tom Bullen and Stepan Shvartsev from different communities to honor their huge scientific legacy.

\section{2- Research Topics}

\section{1- Groundwater hydrogeochemistry}

Groundwater characterization is an important topic of this special issue with worldwide contributions in very different contexts. Kurchikov et al. (2019), for instance, presented the results of the hydrogeochemical spatial pattern modelling in the Cretaceous and Jurassic sediments of the Koltogor 
and Tolkin megatroughs and the surrounding areas of the West Siberian megabasin. They revealed substantial heterogeneity of hydrogeochemical conditions. Seminsky and Seminsky (2019) conducted a systematic study of groundwater radioactivity in the territories around Lake Baikal in Siberia, showing that 1 / faulting is one of the main causes of radon anomalies (as groundwater in the fault zones is enriched with ${ }^{222} \mathrm{Rn}$ due to the increased permeability of rocks and rock crushing resulting from displacements of the fault walls) and that $2 /$ seasonal variations in air temperature and atmospheric pressure lead to changes in groundwater temperature, dilution of groundwater due to precipitation, freezing the top layer of soil, and other phenomena. Alexeev et al. (2020) investigated brines of the Siberian platform, and their geochemical and stable isotope data $\left({ }^{18} \mathrm{O},{ }^{2} \mathrm{H},{ }^{37} \mathrm{Cl},{ }^{81} \mathrm{Br}\right.$, ${ }^{87} \mathrm{Sr} /{ }^{86} \mathrm{Sr}$ ) showed that chloride sodium ground brines of the Siberian Platform originated as the result of halogenous rock leaching, whereas chloride calcium brines derived from buried bittern connate waters. The main evolutionary process was a long interaction in the water/rock system. In addition, the authors highlighted the extremely high potential of this resource as it may constitute a serious alternative to solid mineral deposits. Guo et al. (2020) studied major ions and arsenic of geothermal water by comparing Xiong'an and Yangbajain hydrothermal systems in China. They concluded that arsenic coupled with other hydrochemical constituents can be used as a useful tool to identify the geological geneses of these geothermal waters. In her article, Dutova (2020) investigated geochemistry of fresh groundwater in the Altai-Sayan folded area and adjacent areas of the West Siberian plate. This study contributed to better understand the regional geochemistry of fresh groundwater and showed the spatial patterns of chemical-composition variations in the groundwater. Kulakov and Berdnikov (2020) studied hydrogeochemical processes in the Tunguska reservoir during in situ treatment of drinking water supplies. This paper presented the results of a study of natural hydro-geochemical processes in the zone of the Tunguska aquifer, and changes in these processes caused by in situ water preparation. Frei et al. (2020) studied the link between surface water and groundwater-based drinking water using strontium isotopes in Denmark. Borzenko et al. (2020) studied formation conditions of soda-type groundwater in the south-eastern Transbaikal region (Russia). The stage of soda-type groundwater formation was found to be at an intermediate level between the formation of fresh bisiallite $\left(\mathrm{Ca}-\mathrm{HCO}_{3}\right)$ water of different cationic composition and salt $\left(\mathrm{Na}-\mathrm{HCO}_{3}-\mathrm{Cl}-\mathrm{SO}_{4}\right)$ water with mixed anionic composition. Priebe et al. (2020) investigated recharge and groundwater evolution in a glaciated, regional-scale carbonate bedrock aquifer system in southern Ontario (Canada). This multi-tracer approach was performed to provide the scientific support for regional-scale water policy development in addition to providing guidance to others working in similar glaciated carbonate settings. Kazak and Pozdniakov (2020) reported the results of field study and reactive simulation of iron migration in groundwater during the riverbank filtration. They found that iron accumulates in bottom sediments due to suspension matter precipitation mainly as iron hydroxides. Finally, Saeed et al. (2021) reported elemental and isotopic data for groundwaters to identify the origin and mechanisms of groundwater salinization in three major Tertiary aquifers in Saudi Arabia.

\section{2- Soil and Critical Zone characterization}

This topic brings together contributions dealing with soil and critical zone characterization at different scales and in different contexts worldwide. For instance, Vodyanitskii and Minkina (2019) characterized non-stable Fe minerals in waterlogged soils and investigated the content and composition of non-stable Fe minerals for defining the gley type in their soils. Vodyanitskii et al. (2020) studied the content of mobile compounds of heavy metals ( $\mathrm{Zn}, \mathrm{Pb}$ and $\mathrm{Cu}$ ) in hydromorphic soils from southern European Russia. Li et al. (2020) reported riverine Mg isotopes to constrain 
glacial weathering within the Muztag catchment of the eastern Pamir Plateau. Their results suggest preferential carbonate weathering under glacial environment, different from the process of $\mathrm{Mg}$ isotopic fractionation by secondary mineral formation. In their paper, Zippa and Zuddas (2020) have estimated the reactive surface areas of the most abundant reacting minerals in the granite hydrothermal field of Jiangxi Province in South-East China. Their results showed that the reactive surface area of biotite can play an important role in the $\mathrm{CO}_{2}$ control (source vs. sink). In his article, Novikov (2020) presented a novel numerical modelling approach to physicochemical evolution of water/rock interactions in Upper Jurassic sediments in the Nadym-Taz interfluve (Arctic regions of Western Siberia) in order to better constrain of the nature and mechanisms of diagenetic and catagenetic transformation of sediments experiencing burial in sedimentary basins.

\section{3- Environmental fingerprinting and monitoring}

This topic is of major importance in this special issue with numerous contributions using different geochemical approaches. Houle et al. (2021) tested a novel approach based on the measurements of $\mathrm{Ca}$ and $\mathrm{Sr}$ concentrations and $\mathrm{Sr}$ isotope signature $\left({ }^{87} \mathrm{Sr} /{ }^{86} \mathrm{Sr}\right)$ in sequential extracts of sugar maple tree rings and soils to assess changes in Ca availability and sources through time in Canada. Millot et al. (2020) illustrated two different and complementary applications of lithium (Li) isotope tracers for river-basin characterization at two different scales in France. They highlighted that Li isotopes can be good tracers of weathering conditions and of anthropogenic sources in an urbanized watershed. In the context of mine environment in Sardinia (Italy), Dore et al. (2020) studied the release of metals to water during weathering of ore minerals and mine-waste as well as natural attenuation. Boguslavsky et al. (2020) performed environmental monitoring of low-level radioactive waste disposal in the vicinity of former and currently operating uranium enrichment plants (Zelenogorsk, Russia). Pribil et al. (2020) studied mercury distribution using isotopic fractionation of mercury processes and sources adjacent and downstream of a legacy mine district in Tuscany, Italy. More precisely, Hg speciation in concert with $\mathrm{Hg}$ isotope ratios was shown to better ascertain source attribution and assist in identifying $\mathrm{Hg}$ pathways into the environment to distinguish the more bioavailable forms of $\mathrm{Hg}$ entering the ecosystem. In their article, Négrel et al. (2020) studied Li and $\delta^{7} \mathrm{Li}$ in the Dommel River (Meuse basin, The Netherlands), and after the characterization of an anthropogenic influence using $\delta^{7} \mathrm{Li}$ and mixing equations, they added constraints on the water/substratum interaction highlighting the role of water-residence time in the system on weathering intensity. Kousehlar and Widom (2020) applied a multi-tracer biomonitoring approach for identifying the sources of atmospheric toxic metals in Middletown, Ohio. Their data demonstrate the effectiveness of combining $\mathrm{Pb}$ and $\mathrm{Nd}$ isotopes, in addition to metal concentrations, for atmospheric toxic metal source apportionment in complex environments. These results also highlight the importance of using a multi-tracer approach when investigating the sources of atmospheric pollutants in mixed-use areas. Scott et al. (2020) evaluated the effects of a known exposure source on $\mathrm{Pb}$ isotopes in bones from $\mathrm{Pb}$-dosed cows. They concluded that the $\mathrm{Pb}$ isotopic composition of bone provides a weighted average of bioaccumulated $\mathrm{Pb}$ sources. Kríbek et al. (2020) reported a study where they determined the extent of the uptake of selected trace elements by birch (Betula pendula Roth) growing on the partly burnt coal waste pile and to evaluate isotopic fractionation of $\mathrm{Cu}$ and $\mathrm{Zn}$. Their results showed that $\mathrm{Cu}$ in sap and leaves is depleted in heavy isotope regardless of plant-available concentration of $\mathrm{Cu}$ in substrates, whereas for $\mathrm{Zn}$, no isotopic fractionation or enrichment of $\mathrm{Zn}$ in the heavy isotope was recorded. Zhang et al. (2020) studied source apportionment of cadmium pollution in agricultural soil based on cadmium isotope ratio analysis. In their article, they evidenced that $\mathrm{Cd}$ isotope analysis is a promising tool to accurately identify the heavy metal pollution sources. Christofi et al. (2020) investigated isotope 
hydrology and hydrogeochemical modeling of Troodos Fractured Aquifer (Cyprus) in order to develop better hydrogeological descriptions of water types in this context (evolution path along an ophiolite transect). Desaulty et al. (2020) reported $\mathrm{Zn}$-isotope signatures in stream sediments and waters to track anthropogenic sources in a small catchment in France.

\section{4- Climate change and geochemical records}

In this topic, Paulsson and Widerlund (2020) studied four pit lakes for oxygen and hydrogen isotopic composition in subarctic Sweden to better understand hydrogeological processes in this specific environment. In their study, Vasil'chuk et al. (2020) reported major and trace elements, $\delta^{13} \mathrm{C}$, and polycyclic aromatic hydrocarbons in the Late Pleistocene ice wedges in order to determine whether there are fluctuations of chemical composition due to different ages of ice wedges. Ukraintsev et al. (2020) reported the results of long-term observations of the formation of atmospheric pollution by fine particles in burnt forest areas and in the surrounding areas. They conducted a specific study on the morphology and chemical composition of dispersed particles in the snow cover of burnt forest areas in Western Transbaikalia (Russia). And finally, Belyanin et al. (2020) reported the results of radioisotopes ${ }^{7} \mathrm{Be},{ }^{210} \mathrm{~Pb},{ }^{137} \mathrm{Cs}$ and ${ }^{40} \mathrm{~K}$ in the needles of larch and cedar in the Novy Urengoy region (Arctic part of Western Siberia) in order to assess the aerosol deposition on vegetative canopies of larch.

\section{5- Bio-geochemistry of Water/Rock interactions.}

The topic of bio-geochemistry gathers several contributions in the special issue. For instance, Savichev et al.(2020) studied geochemical barriers in oligotrophic peat bog in Western Siberia, focusing on the distribution of chemical elements in peat deposits and, particularly, the causes of the formation of some minerals in the peat deposits. Nechaev et al. (2020) studied bio-geochemical evolution and critical element mineralization in the Cretaceous-Cenozoic coals from the southern Far East Russia and northeastern China, in order to further constrain geodynamic and other geological processes controlling bio-geochemical compositions and critical element mineralization of the studied coals. In their article, Khaustov and Redina (2020) studied the fractioning of the polycyclic aromatic hydrocarbons in the components of the non-equilibrium geochemical systems by thermodynamic analysis. Bai et al. (2020) worked on multi-isotope constraints on biogeochemical processes during bank filtration (the Liao River, Northeast China). Their results showed that carbon, iron and sulfur isotopes can be good indicators of biogeochemical processes during river water infiltration. Finally, Leonova et al. (2020) reported the results of a biogeochemical study of Holocene peatlands in the Baraba forest-steppe (southern West Siberia). They focused in their study on the characterization of post-depositional diagenetic processes and behavior of biogenic elements.

\section{Acknowledgments}

We acknowledge all the authors for their contributions, not only those who have attended the $16^{\text {th }}$ International Symposium on Water-Rock Interaction and $13^{\text {th }}$ International Symposium on Applied Isotope Geochemistry (WRI16 \& AIG13, merged into the $1^{\text {st }}$ International IAGC-Conference) held at Tomsk, Siberia, Russia, July 21-26, 2019. 
Moreover, we would like to thank the authors for their patience with the review process as well as the reviewers for their constructive comments and remarks. Their efforts have improved the quality of this Special Issue. We are extremely grateful to Prof. Dr. Michael Kersten, Editor-in- Chief of APGEO and Praveen Johnson, Journal Manager, without whose knowledge and experience this Special Issue could never have been published. 


\section{Declaration of competing interest}

The authors declare that they have no known competing financial interests or personal relationships that could have appeared to influence the work reported in this preface. 